\title{
Validity of Agreements Using Foreign Languages in the Legal System in Indonesia
}

\author{
Elly AM Pandiangan ${ }^{1}$, Nanin Koeswidi Astuti ${ }^{2}$, Cristoper Sirait ${ }^{3}$ \\ \{elly.pandiangan@uki,ac,id\} \\ Fakuktas Hukum Universitas Kristen Indonesia ${ }^{123}$ \\ Jl.Mayjen Sutoyo No 2, Cawang Jakarta Timur, Indonesia
}

\begin{abstract}
The agreement in civil law is a very important aspect and almost every part of the civility knows the terms of the agreement, but problems arise in the application of this agreement, one of which is about the choice of the language of an agreement that is when the agreement is held by a foreign party with the Indonesian side. The problem formulation in this study is the extent of the application of the principle of freedom of contract in the use of language in treaties according to the legal system in Indonesia and how the validity of foreign language agreements is reviewed from the Decree no. 451/Pdt.G/2012/PN.Jkt.Bar.In this paper, the author uses normative legal research method, where the author conducts data collection through library research based on data relevant to the subject matter to be discussed. Studies, libraries that will be done by reading, analyzing the materials-literature materials. Based on the analysis conducted by the author, in the language selection of a basic agreement on freedom of contract does not apply due to the obligation to use the Indonesian language in making an agreement as stipulated in Article 31 of Law No. 24 of 2009. and the validity of the agreement using foreign languages is reviewed from The Decree No. 451/Pdt.G/2012/PN. Jkt.Bar. if the agreement is not accompanied by Indonesian language, then the agreement is null and void. until the verdict in this case invalidates the principal agreement and its follow-up agreement.
\end{abstract}

Keywords: Agreement; Foreign Language; language

\section{Introduction}

Law in people's lives certainly has a very big meaning because almost every aspect of people's lives will always be related to the law and without law, in the midst of people's lives, there will be very severe chaos. In the context of social relations, the legal dimension can be understood as a rule or norm which is a guide to life and guidelines for proper or expected behavior. Here the law intends to regulate the order of society. Therefore, when the life instructions containing these commands and prohibitions are violated, it can lead to action in the form of sanctions from the government or community authorities. As the formulation of the various definitions of legal experts, the so-called law consists of 4 elements: 1) Regulations regarding human behavior in public relations. 2) are held by authorized official bodies. 3) Regulations are coercive, meaning that everyone must obey or obey the law, and 4) Sanctions for such violations are strict.

The law can actually be classified into several groups or categories based on several sizes so that a better understanding can be obtained, and it is easier to find and apply it. From the 
classification, the most important thing is the division of law based on its contents, namely public law and private law. Public law is the law that regulates the relationship between the state and state tools or equipment or the relationship between the state and its citizens. Public law consists of: state administrative law, state administrative law, criminal law, international law.

Material international law sources are defined as the basis for the application of international law, to answer the question of what causes international law to be binding. Second, sources of international law are sometimes defined as the main factor or force that causes international law to emerge. These factors are usually political, societal, economic, technical, psychological, and so on. Our foundation in determining sources of international law in a formal sense is Article 38 of the Charter. International Court of Justice. Article 38 paragraph 1 of the charter of the International Court of Justice states that in adjudicating a case brought against it, the International Court of Justice will use:

a. International agreements, both general and specific, which contain provisions that are expressly regulated by the disputing countries.

b. International custom, as evidence of a general practice accepted as law.

c. Principles of general law recognized by civilized nations.

d. Court decisions and teachings of the most eminent scholars from various countries.

The source of material law is everything that determines the content of the law. Meanwhile, formal sources of law can be interpreted in two ways: as a place to find the law and as a binding basis. According to Starke, material legal sources of international law are defined as actual materials used by international legal experts to determine the law that applies to a particular event or situation. Private law is the law that regulates the relationship between one person and another, with an emphasis on personal or personal interests [1]. In a broad sense, it includes civil law and commercial law, while in a narrow sense private law is civil law.

In Indonesia, civil law has long been familiar with the contents of civil law and has applied various aspects of civil law in daily life and to this day in Indonesia civil law still applies, in simple terms, the meaning of civil law itself is the rules governing the relationship between individuals (private) in society and law This civil law is basically regulated in the KUHPER (book of civil law laws) or also known as burgerlijk wetboek. from this simple understanding, we can see that the scope of this civil law regulation is the relationship of rights and obligations between individuals and individuals. Some legal experts in Indonesia have various opinions about the definition of civil law itself, as follows: Prof. Subekti's understanding of civil law is all material private law, namely all basic laws that regulate individuals.

The definition of Civil Law according to Prof. Sudikno Mertokusumpo is a whole arrangement that studies the relationship between people with one another in family relationships and in community relationships. Civil Law according to Prof. Dr. R. Wirjono Prodjodikoro S.H. is a series of persons or legal entities with each other regarding rights and obligations. In this civil law there are principles or which, become the basic principles of civil law, namely:

\section{The principle of freedom of contract}

The principle of freedom of contract is a principle which implies that anyone can enter into any agreement, whether regulated in law or not yet regulated in law. This principle is contained in Article 1338 paragraph 1 of the Civil Code which states that "all agreements made legally apply as law for those who make them". The principle of freedom of contract can 
be analyzed from the provisions of Article 1338 paragraph (1) of the Civil Code, which reads: " All agreements made legally apply as law to those who make them. This principle is a principle that gives freedom to the parties to:

a. make or not make an agreement;

b. enter into an agreement with anyone;

c. determine the contents of the agreement, its implementation, and its requirements;

d. determine the form of the agreement, whether written or oral.

1. The principle of consensual

It is a principle that relates to the birth of the agreement. In Article 1320 paragraph 1 of the Civil Code, the condition for the validity of the agreement is because there is an agreement between the two parties. This principle means that an agreement is born from the moment an agreement is reached between the two parties. This is in accordance with the conditions for the validity of an agreement.

2. The principle of trust

That is the principle which implies that everyone who will enter into an agreement will fulfill every achievement made between them as the difference between criminal and civil law and examples.

3. The principle of binding strength

That is the principle which states that the agreement is only binding on the parties who bind themselves or are involved in the agreement. Article 1340 of the Civil Code reads: "Agreements are only valid between the parties who make them." This implies that the agreement made by the parties only applies to those who make it. However, this provision has an exception as in Article 1317 of the Civil Code which states: "An agreement can also be made for the benefit of a third party, if an agreement made for oneself, or a gift to another person, contains such a condition."

4. The principle of legal equality

That is the principle which implies that the legal subject who makes the agreement has the same position, rights, and obligations in law as in the example of customary law.

5. The principle of balance

That is the principle that both parties want to fulfill and carry out the promised agreement.

6. The principle of legal certainty (Pacta sunt servada)

That is the principle that results from an agreement and is regulated in Article 1338 paragraphs 1 and 2 of the Civil Code. This principle can be concluded from the word "applies as law for those who make it". The principle of pacta sunt servanda can be concluded in Article 1338 paragraph (1) of the Civil Code. This principle was originally recognized in church law. In church law, it is stated that an agreement occurs when there is an agreement between the parties who do it and is confirmed by oath. This implies that every agreement made by both parties is a sacred act and is associated with religious elements. However, in subsequent developments asaspacta sunt servanda was given the meaning of pactum, which means an agreement that does not need to be strengthened by oaths and other formalities. While the term nudus pactum is enough with just an agreement.

7. Moral principles

That is the principle that is bound in a fair engagement, meaning that the act of a person who voluntarily cannot claim the right for him to sue the debtor's achievements in the example of positive law. 


\section{Protection Principle}

That is the principle that provides legal protection between debtors and creditors. However, what needs to be protected is the debtor because he is in a weak position according to the legal function of the expert.

9. The principle of propriety

That is the principle relating to the provisions regarding the contents of the agreement required by propriety. The principle of propriety is contained in Article 1339 of the Civil Code. This principle relates to the provisions regarding the content of the agreement which is required by propriety based on the nature of the agreement for the purpose of criminal procedural law

10. Principles of personality

That is the principle that requires a person to enter into an agreement for his own sake. This can be seen in Article 1315 and Article 1340 of the Civil Code. Article 1315 of the Civil Code states: "In general, a person cannot enter into an engagement or agreement other than for himself." The essence of this provision is clear that to enter into an agreement, the person must be for his own benefit.

11. The principle of good faith

Namely the principle related to the implementation of the agreement, this principle states that whatever must be done by fulfilling the demands of justice and not violating propriety. This is in accordance with Article 1338 paragraph 3 of the Civil Code. This principle is the principle that the parties, namely the creditor and debtor, must carry out the substance of the contract based on firm trust or confidence as well as the goodwill of the parties. The principle of good faith is divided into two types, namely relatively good faith and absolute good faith. In the first intention, one pays attention to the real attitude and behavior of the subject. In the second intention, the assessment lies in common sense and justice, and an objective measure is made to assess the situation (impartial assessment) according to objective norms [2]. Civil law also has four books which are the main parts based on the KUHPER, namely: about people, about objects, about engagements, and proof and expiration. Which of the four main sections that will be discussed is book three about engagement?

The meaning of law of engagement (verintensis) is a legal relationship between two parties in the field of property, where one party (the creditor) is entitled to achievement, and the other party (the debtor) is obliged to fulfill that achievement. According to Subekti, an engagement is said to be a legal relationship between two people or two parties, based on which one party has the right to demand something from the other party, and the other party is obliged to fulfill that claim. Furthermore, it is said that the party who has the right to demand something is called the creditor or the debtor, while the party who is obliged to fulfill the claim is called the debtor or the debtor. Because the relationship between the debtor and creditor is legal, this means that the creditor's rights are guaranteed by law. This is emphasized again based on the provisions of Article 1338 paragraph (1) of the Civil Code which states that all agreements made legally apply as law for those who make them. Based on that, if one of the parties does not fulfill the demands of the other party voluntarily, the creditor can sue him in court [3].

In the engagement, the discussion will be very closely related to the agreement because these two things are two things that can be said to always be present simultaneously where an agreement is an event where one person promises to another or where two people promise each other to carry out something. From this event, a relationship arises between the two people which is called an engagement. The agreement publishes an agreement between the two people who make it. In its form, the agreement is in the form of a series of words containing promises or promises that are spoken or written. 
Thus, the relationship between the engagement and the agreement is that the agreement issues the engagement. The agreement is the source of the engagement, in addition to other sources. An agreement is also called an agreement. Because the two parties agreed to do something. It can be said that the two words (agreement and agreement) have the same meaning. The word contract is narrower because it refers to a written agreement or agreement.

The agreement is the most important source that gives birth to the engagement. Indeed, most of the engagements are issued by an agreement, but as already said, there are other sources that give birth to engagements. These other sources are included under the name of the law. So, there are engagements born from "agreements" and there are engagements born from "laws" [4]. The meaning of an agreement in the Civil Code is regulated in Article 1313 of the Civil Code which reads "agreement is an act by which one or more parties bind themselves to one or more people." However, according to the author's opinion, the contents of this article do not reveal the true meaning of the agreement if we compare the terms of the validity of an agreement.

The conditions for the validity of an agreement are regulated in Article 1320 of the Civil Code which states four conditions for the validity of an agreement, namely: the agreement of those who bind themselves, the ability to make an engagement, a certain matter, a lawful cause. In the contents of this article, we can see that there are several elements in the agreement that must be fulfilled so that the agreement can be legally enforceable [5].

Agreements and contracts to this day have occurred both between Indonesian citizens and Indonesian citizens to the existence of cross-border agreements, so it is possible that the language in this agreement becomes a fairly basic problem. After understanding the description of the background above and based on the existing legal provisions, several points of discussion that will be the formulation of the problem in this thesis are as follows: The extent to which the application of the principle of freedom of contract in the use of language in agreements according to the legal system in Indonesia and how the validity of foreign language agreements in terms of decision number 451/Pdt.G/2012/PN.Jkt.Bar. In this study, the author focuses on discussing the validity of the use of agreements in foreign languages according to the Indonesian legal system with an emphasis on the Civil Code and Law No. 24 of 2009 concerning the flag, language, and coat of arms of the state as well as the national anthem.

The objectives of this research are Objective: the extent to which the application of the principle of freedom of contract in the use of language in agreements according to the legal system in Indonesia and how the validity of foreign language agreements is viewed from decision number 451/Pdt.G/2012/PN.Jkt.Bar. while the Subjective objectives: broaden the author's horizons regarding contract law and complete one of the requirements in achieving a bachelor's degree in law at the Faculty of Law, Indonesian Christian University.

\section{Theoretical Framework and Research Methods}

\subsection{Theoretical Framework Covenant Theory}

According to book III regarding engagement in article 1313, namely the relationship of a legal act by two or more people will give rise to rights and obligations for each party who has bound themselves. The agreement has the freedom to fill out each clause in accordance with the achievements to be achieved by both parties in accordance with the law. According to the 
opinion expressed by R. subekti, an agreement is an event where a person or party promises to another party or the two parties promise to carry out something [6].

\section{Principles in the agreement}

1. Principle of Freedom of Contract

The principle of freedom of contract is contained in Article 1338 paragraph (1) of the Civil Code. Freedom in making agreements where the parties can freely regulate the rights and obligations in the agreed agreement. According to Subekti in his Book of Covenant Law, the principle of freedom of contract is a principle which states that basically everyone can make a contract (agreement) that contains and is of any kind as long as it does not conflict with the law, decency and public order. Freedom of contract does not mean the parties can make a contract (agreement) freely, but still heed the terms of the validity of the agreement, both the general conditions as determined by article 1320 of the Civil Code, as well as the special conditions for certain agreements.

According to Munir Fuady, the principle of freedom of contract gives the parties the freedom to make or not make a contract, as well as the freedom to regulate the contents of the contract themselves [7]. This principle is implied in Article 1338 of the Civil Code, essentially stating that there is freedom to make any contract as long as it does not conflict with law, order and morality. Subekti in his book Principles of Civil Law, states that people are free to make any kind of agreement, as long as they do not violate public order or morality, in general they are also allowed to override the regulations contained in Book III because Book III is a "complementary law" (aanvullend recht) is not a hard law or a coercive law [8]. Historically, freedom of contract actually includes five kinds of freedom, namely:

a. the freedom of the parties to close or not to close the contract.

b. freedom to determine with whom the parties will conclude the contract.

c. the freedom of the parties to determine the form of the contract.

d. the freedom of the parties to determine the contents of the contract.

e. freedom on the part of the parties to determine how to close the contract.

According to Felix O. Soebagjo, in the application of the principle of freedom of contract, does not mean that it can be carried out freely, but there are also restrictions imposed by the legislators, which are not contrary to public order, decency and decency [9].

2. Binding Principle as Law

This principle is also known as Pacta Sunt Servanda, that the agreement binds the parties who entered into it or every agreement must be adhered to and adhered to [10]. All agreements made legally apply as law for those who make them, and these agreements cannot be withdrawn other than by agreement of the parties or for reasons determined by law. And the agreement must be made in good faith. An important thing that should be noted is that the agreement is not only binding for things that are expressly stated in it, but also for everything that according to the nature of the agreement is required by propriety, custom, or law. This legal principle has put the position of the agreement made by the community into law for him so that the State is no longer authorized to interfere in the agreement.

The parties must fulfill what they accept as their respective obligations because the agreement is a law for the parties who entered into it and the binding force is considered the same as the statutory power, so the term Pacta Sun Servanda means "the promise is binding". The binding of the parties to the agreement is not only limited to what was agreed, but also to several other elements as long as it is desired by habit and moral propriety [11]. 


\section{Principle of Consensually}

As implied in Article 1320 of the Civil Code, that a contract has already taken place and therefore binds the parties to the contract since an agreement is reached on the main elements of the contract. In other words, a contract is valid if an agreement has been reached on the main elements of the contract and no certain formalities are required. Many questions, when is the time for the agreement in the agreement to occur. The agreement will arise if the parties who make the agreement at one time are together in one place and that is where the agreement occurs.

However, in practice it does not happen so often, and many agreements occur by correspondence, so the question of when the agreement takes place is also raised. This is important because for agreements that are subject to the principle of consensually, the time of the agreement is the time of the agreement [12]. The binding power of a contract is born when there has been an agreement, or known as the principle of consensually, where the parties who promise have agreed to bind themselves in a legal agreement. This principle can also be found in Article 1338 of the Civil Code, in the term "all". The words "all" indicate that each person is allowed to express his or her perceived good wishes to make a pact.

4. Good Faith Principle

The principle of good faith in an agreement is contained in Article 1338 paragraph (3) of the Civil Code. Which states the agreements must be carried out in good faith. However, the article does not explicitly state what is meant by "good faith". As a result, people will have difficulty in interpreting the good faith itself. Because good faith is an abstract understanding that relates to what is in the human mind. According to James Gordley, as quoted by Ridwan Khairandy, in reality it is very difficult to define good faith [13]. In practice the implementation of the agreement is often interpreted as relating to compliance and appropriateness in carrying out a contract.

According to the classical theory of contract law, the principle of good faith can be applied in situations where the agreement has fulfilled certain conditions, as a result of this teaching it does not protect the party who suffers losses in the pre-contract or negotiation stage, because at this stage the agreement has not met certain conditions [14].

The application of the principle of good faith in business contracts must be considered, especially when conducting pre-contract agreements or negotiations, because good faith is only recognized when the agreement has fulfilled the conditions for the validity of the agreement or after negotiations have been carried out. Regarding the possibility of harm to the implementation of the principle of good faith, Suharnoko said that the Consumer Protection Act implicitly recognizes that good faith must exist before signing the agreement, so that precontract promises can be held accountable in the form of compensation, if the promise is broken.

\subsection{Research Methods}

This study obtains the data source is a normative legal research method, where the authors collect data through library research based on data relevant to the subject matter to be discussed. Study, literature that will be carried out by reading, analyzing existing library materials to develop the data obtained. This normative legal research method is a method that refers to the legal norms contained in the applicable laws and regulations. This study uses secondary data types. Materials from secondary data are divided into 3 (three) which will be used including: Primary Legal Materials, which consist of: Civil Code and Law No. 24 of 2009 on flags, language and state symbols and songs nationality. 
Secondary Legal Materials, sourced from books, journals, articles, and electronic media. For secondary legal materials, the authors take sources from books related to contract law, while Tertiary Legal Materials, namely data that provide instructions and explanations on primary and secondary data. This tertiary legal material is in the form of a Legal Dictionary and Encyclopedia and so on.

\section{Results and Discussion}

\subsection{The meaning of Agreement in General}

The term "agreement" in contract law is the equivalent of "overeekompst" in Dutch or "agreement" in English. Therefore, the term "contract law" has a narrower scope than the term "commitment law" if the term "commitment law" is intended to cover all forms of engagement in the third book of the Civil Code, so it includes legal bonds originating from agreements and legal bonds issued. from the law, then the term "covenant law" is only intended as a regulation of legal bonds issued from the agreement [16]

\section{Definition of Agreement}

An agreement is an event when a person promises to another person or when that person promises to each other to carry out something. In this agreement, a legal relationship arises between the two people/engagement [17] Many definitions of agreement have been given by experts, but what needs to be known from the point of view of which agreement is defined so that it is possible that each definition highlighted is different. One definition of an agreement/contract is that a contract is a part of a promissory agreement between two or more parties that can create, modify, or eliminate legal relationships. Then there are also those who give the meaning of a contract as an agreement, or a series of agreements where the law provides compensation for default on the contract, or against the implementation of the contract by law is considered a duty [18] Article 1313 states that the definition of an agreement is as follows "An agreement is an agreement in which one or more persons bind themselves to one or more other persons".

Civil law scholars generally argue that the definition of the agreement contained in the above provisions is neither complete nor too broad. It is not complete because it is formulated only regarding a one-sided agreement. The definition is said to be too broad because it can include actions in the field of family law, such as marriage vows, which are also agreements, but their nature is different from the agreements regulated in the Civil Code Book III, the agreements regulated in the Civil Code Book III the criteria can be assessed materially, in other words with [19] money. An agreement is a concrete and observable event, whether it is a written or unwritten agreement. This is different from an engagement that is not concrete, but abstract or cannot be observed because the engagement is only the result of the existence of the agreement that causes the person or parties to be bound to fulfill what was promised [20].

\section{Definition of Engagement}

Engagement (verbintenis) is a legal relationship between two parties in the field of property, where one party (the creditor) is entitled to achievement, and the other party (the debtor) is obliged to fulfill that achievement. Therefore, in every engagement, there are "rights" on the one hand and "obligations" on the other. According to Subekti, an engagement is said to be a legal relationship between two people or two parties, based on which one party 
has the right to demand something from the other party who is obliged to fulfill that claim. Furthermore, it is said that the party who has the right to demand something is called the creditor or the debtor, while the party who is obliged is called the debtor or the debtor.

In this case, Vollmar stated that in terms of its contents, the engagement existed as long as the person (the debtor) had to perform something that might be enforced on the creditor, if necessary, with the help of a judge [21]. From these various definitions, it can be seen that in this engagement the relationship between the parties is guaranteed by law or in other words the relationship between the debtor and creditor is guaranteed by law, meaning that what is guaranteed by law is that the relationship in this engagement has a legal basis.

The legal basis is contained in Article 1338 paragraph (1) of the Civil Code which states that all agreements made legally apply as law for those who make them. Not only that, the engagement as contained in book III of the Civil Code states that the engagement has two (2) kinds of sources, namely Article 1233 of the Civil Code "every engagement is born good because of the good agreement by law". Based on Article 1233 of the Civil Code, it is clear that the two (2) kinds of sources of engagement are engagements born out of approval and engagements born out of the law. An agreement or agreement is an event in which a person promises to do something. From this event arises a relationship between the two people which is called an engagement. In other words, the agreement publishes the engagement between the two people who made it [22]

\section{Agreement Legal Arrangements}

The legal arrangements of the agreement are contained in the Civil Code Book III which contains 18 chapters of which of the eighteen chapters there are 631 articles, namely between Article 1233 of the Civil Code to Article 1864 of the Civil Code. These 18 chapters are divided into two parts, the first part is called the general part consisting of chapters I - chapter IV, and the second is called the special part starting from chapter V - chapter XVII the special part is also called the named agreement (nominaat) because of the forms of the agreement. in this section already has a special name and already has special regulations determined by the legislators, namely as follows:

a. Matters regulated in Article 1233 to Article 1312 of the Civil Code, include the source of the engagement; performance; reimbursement of costs, losses, and interest due to nonfulfillment of an engagement; and types of engagement.

b. Engagements born from agreements (Article 1313 to Article 1351 of the Civil Code)

c. The abolition of the engagement (Article 138I to Article 1456 of the Civil Code)

d. Buying and selling (Article 1457 to Article 1540 of the Civil Code) matters regulated in Article 1457 to Article 1540 of the Civil Code of Exchange (Article 1541 to Article 1546 of the Civil Code)

e. Leasing (Article 1548 to Article 1600 of the Civil Code)

f. Approval to do work (Article 1601 to Article 1617 of the Civil Code)

g. Fellowship (Article 1618 to Article 1652 of the Civil Code)

h. Legal entity (Article 1653 to Article 1665 of the Civil Code)

i. Grants (Article 1666 to Article 1693 of the Civil Code)

j. Safekeeping of goods (Article 1694 to Article 1739 of the Civil Code)

k. Borrow and use (Article 1740 to Article 1753 of the Civil Code)

1. Borrowing (Article 1754 to Article 1769 of the Civil Code)

m. Fixed or perpetual interest (Article 1770 to Article 1773 of the Civil Code)

n. Chance agreement (Article 1774 to Article 1791 of the Civil Code).

o. Granting power of attorney (Article 1792 to Article 1819 of the Civil Code). 
p. Insurers of debt (Article 1820 to Article 1850 of the Civil Code).

q. Peace (Article 1851 to Article 1864 of the Civil Code)

The existence of a named agreement (nominaat) also publishes an unnamed agreement (innominaat) where the legal basis of an anonymous agreement is contained in Article 1338 of the Civil Code. An unnamed agreement (innominaat) grows and develops according to the needs of the community, the parties who make this anonymous agreement can give a special name to the agreement they made based on an agreement from both parties.

\section{Terms of Validity of Agreement}

An agreement must meet the conditions specified so that the agreement can be implemented, as contained in the legal terms of an agreement where the provisions are contained in Article 1320 of the Civil Code, namely there are 4 (four) conditions that must be fulfilled so that an agreement can be implemented where 4 (four) these conditions consist of 2 (two) elements, namely a subjective element and an objective element, the conditions for the validity of an agreement are regulated in Article 1320 of the Civil Code:

a. There is an agreement from those who bind themselves (the parties). By agreeing, it is meant that the parties who agreed must agree, agree on the main things of the agreement that was entered into. What does the other party want? The agreement of both parties in an agreement must be given freely. In this case, there should be no coercion (dwang), oversight (dwaling), deception (bedrog).

b. Both parties are legally competent to act on their own. According to Article 1330 of the

Civil Code, those who are not qualified to make agreements are:

- immature people.

- Under pardon/curatele.

- Women, who are married (with the existence of SEMA; circular letter of the Supreme Court No. 3 of 1963 and the 1974 Law on marriage, this provision is no longer valid). According to article 33 of the Civil Code, minors are those who have not reached the age of 21 and are not married.

a. A certain thing that is agreed upon. A certain thing means that the type of goods that are the object of the agreement must at least be able to be determined; while the amount does not matter as long as it can be determined later. For example: buying and selling rice harvests from a field in the coming year is legal.

b. A cause that is allowed the cause or causes referred to by the law is the content of the agreements themselves. That is, it is not prohibited by law, does not conflict with the public interest and moral norms. What is meant by the cause or clause here is not the cause that encourages the person to agree. The cause or cause of an agreement is a common goal to be achieved by the parties [23].

The first and second conditions are called subjective conditions, if the agreement does not meet one of these conditions, it can be canceled/erneitigbaar, meaning that one of the parties who feel aggrieved can request cancellation. The third and fourth conditions are called objective conditions, if the agreement does not fulfill one of these conditions, it is null and void, that is, from the beginning, it was considered that there was no agreement [24]. And when all the conditions mentioned in Article 1320 of the Civil Code are fulfilled both subjective and objective conditions, the legal consequence is that the agreement can be implemented, or the agreement can apply to the parties. 


\section{Covenant Law Principles}

In contract law there are a number of very basic principles and have a very important role in this contract law, it is said to be very important because these principles are the basis of thought in contract law. Namely: the principle of freedom of contract, the principle of consensual, the principle of Pacta Sunt Servanda, the principle of good faith (Goede Trow), the principle of personality

\section{Use of Indonesian in the Agreement}

Regarding the use of the Indonesian language in the agreement, the Government of the Republic of Indonesia has issued Law no. 24 of 2009 concerning the State Flag, Language, and Emblem, as well as the National Anthem (State Emblem Law). One of the things regulated in the law above is regarding the use of the Indonesian language in agreements, Then in the State Emblem Law it is also regulated regarding the use of the Indonesian language in making agreements with foreign parties, these matters are regulated in Article 31 which contains : "(1) Indonesian language must be used in a memorandum of understanding or agreement involving state institutions, government agencies of the Republic of Indonesia, Indonesian private institutions, or individual Indonesian citizens. (2) The memorandum of understanding or agreement as referred to in paragraph (1) involving a foreign party is also written in the foreign party's national language and/or English." As contained in the law, it can be seen that what is meant in the two articles above is that every agreement must be made in Indonesian, whether the agreement involves a foreign legal subject, at least if the agreement is made in a foreign language, the translation must still be made in the Indonesian language.

\section{The validity of the Agreement Using Foreign Languages is reviewed from Decision Number 451/Pdt.G/2012/PN.Jkt.Bar.}

\section{Position Case}

In April 2010 there was a loan agreement between Nine AM Ltd. (Defendant) who provided a loan to PT. Bangun Karya Pratama Lestari (Plaintiff), where the accessory agreement is a fiduciary guarantee for heavy equipment owned by PT Bangun Karya Pratama Lestari, in this case, the fiduciary guarantee agreement is made before a notary and made in Indonesian but the main agreement, namely the loan agreement, is only made in one language, namely English, the loan agreement is made and signed and is subject to legal provisions in Indonesia. Then PT Bangun Karta Putra Lestari (Plaintiff) filed a lawsuit for the cancellation of the loan agreement because the loan agreement only uses English while Law Number 24 the Year 2009 stipulates that an agreement must be in Indonesian.

\section{Judge's Consideration}

In Decision Number 451/Pdt.G/2012/PN.Jkt.Bar, the panel of judges will first consider the legal relationship between Plaintiff and Defendant in connection with the Loan Agreement signed by Plaintiff and Defendant on 23 April 2010 which has been prepared by Defendant where Plaintiff resides. only signed, made in English and the Loan Agreement which had been signed by Plaintiff only the Plaintiff obtained from Defendant $+1-1$ year later. In his response, Defendant stated that the provisions of Article 31 paragraph (1) of the Law of the Republic of Indonesia Number 24 of 2009 could not be applied in the aqua case because the provisions of Article 40 of the Law of the Republic of Indonesia Number 24 of 2009 stated "further provisions regarding the use of the Indonesian language as referred to in Article 26 to Article 39 is regulated in a Presidential Regulation", while the Presidential Regulation has not yet 
been confirmed by the Letter of the Minister of Law and Human Rights of the Republic of Indonesia No. M.HH.UM.01.01.35 dated December 28, 2009, which answered a letter from 11 (eleven) Associates Lawyers regarding Clarification of the Implications and Implementation of the Law of the Republic of Indonesia Number 24 of 2009.

The judge also considered that the Loan Agreement signed by Plaintiff and Defendant dated April 23, 2010, was made in 1 (one) language, namely English without Indonesian. Meanwhile, the Law of the Republic of Indonesia Number 24 of 2009 has explicitly required the Indonesian language to be used in a memorandum of understanding or agreement involving the State, Government agencies of the Republic of Indonesia, citizens, Indonesian private institutions, or individual Indonesian citizens and the binding power of law is the date of promulgation which in this case is from July 09, 2009, so that therefore any agreement or agreement involving the State, Government agencies of the Republic of Indonesia, Indonesian Private Institutions or individual Indonesian Citizens made after July 9, 2009, that does not use the Indonesian language is contrary to the Law of the Republic of Indonesia Number 24 of 2009.

Because the Loan Agreement dated April 23, 2010, made by and between the Plaintiff and the Defendant is null and void, the Deed of Fiduciary Guarantee Agreement on objects dated April 27, 2010 Number 33 which is an accessory agreement to the Loan Agreement dated April 23, 2010, also must be declared null and void. The Defendant/Creditor provided a loan to the Plaintiff/Debtor in the amount of USD 4,422,000 (four million four hundred twenty-two thousand United States Dollars), of which the Plaintiff has paid the Defendant in the amount of USD 3,506,460 (three million five hundred six thousand four hundred sixty United States Dollars) plus a deposit of USD 800,000 which is USD 4,306,460 (four million three hundred six thousand four hundred and sixty United States Dollars) so that the Plaintiff must return the remaining money of the Defendant which is still with the Plaintiff in the amount of USD. 4,422,000 minus USD, 4,306,460 = USD, 115,540.

\section{Amar Judgment}

In Case Number 451/Pdt.G/2012/PN.Jkt.Bar, the Panel of Judges examined and decided the case with the following verdict:

I. In Exception:

Rejecting the Defendant's Exception in its entirety;

II. In Provision:

Reject the Provisional claim of the Plaintiff;

III. In The Matter Of The Matter:

a. Granted the Plaintiff's claim in its entirety;

b. To declare that the loan agreement dated April 23, 2010, made by and between the Plaintiff and the Defendant is null and void;

c. To declare that the Deed of Fiduciary Guarantee Agreement on Objects dated April 27, 2010 Number: 33 which is the Accesoir of the Loan Agreement dated April $23-$ 2010 is null and void;

d. Ordered Plaintiff to return the remaining money from the loan which had not been returned to Defendant in the amount of U\$D 115,540. (one hundred and fifteen thousand five hundred and forty United States Dollars);

e. Sentencing Defendant to pay the costs incurred in this case amounting to Rp.316,000, - (three hundred and sixteen thousand rupiahs). 


\section{Conclusion Analysis Results}

I agree with the Panel of Judges who examined and decided the case had implemented the right law, as for the reasons as follows: The panel of judges examined and decided on case No. 451/Pdt.G/2012/PN.Jkt.The bar has granted the Plaintiff's claim in its entirety, stating that the loan agreement dated April 23, 2010, made by and between the Plaintiff and the Defendant is null and void, and declares that the Deed of Fiduciary Guarantee Agreement on Objects dated April 27, 2010 Number: 33 which is the Accesoir of the Loan Agreement dated April 23-2010 is null and void. The debt agreement is indeed not under the legal requirements of an agreement because it is contrary to the fourth condition, namely "a lawful cause." This fourth condition is an objective condition where the legal consequence is that the agreement is null and void. has included what is meant in Article 1337 of the Civil Code which states:

"A cause is prohibited if it is prohibited by law or if it is contrary to good decency or public order" In the agreement made by both parties, it is included in the first element in Article 1337 of the Civil Code, which is prohibited by law or contrary to the law, in this case, it is stated in Article 31 of Law Number 24 of 2009 that the agreement is mandatory. made in the Indonesian language, while the agreement made by the parties in this case only uses a foreign language, it is clear that this agreement is against the word obligatory in Article 31 of Law Number 24 of 2009.

\section{Conclusion}

The application of the principle of freedom of contract in the use of the Indonesian language in agreements according to the Indonesian legal system which gives freedom to the parties to make agreements, to enter into agreements with anyone, to make agreements in what form and for what purpose the agreement is made, does not apply in an agreement. official, because of the obligation to use the Indonesian language in agreeing as regulated in Article 31 of Law Number 24 of 2009. The validity of the agreement using foreign languages is reviewed from Decision Number 451/Pdt.G/2012/PN.Jkt.Bar. can result in the cancellation of an agreement or the use of a foreign language without being accompanied by Indonesian in an agreement, it can be considered that the agreement has violated the objective elements of the legal requirements of an agreement which results in null and void. In this case, the violation of the objective element has violated the four conditions for the validity of the agreement, namely a lawful cause, so in this violation, it is categorized as a prohibited cause so that the decision, in this case, cancels the main agreement and the accompanying agreement.

There needs to be a renewal of the arrangements in contract law and also maintain the value of the principles contained in the law of the agreement and also need to emphasize matters related to the agreement in the formation of a new arrangement so that everything related to the law of the agreement is summarized in-depth in the arrangement. so that in the future the perpetrators of the agreement and law enforcers can firmly establish a clear legal basis in determining attitudes related to the agreement. Regarding the legality of the agreement using a foreign language, it is advisable for the parties who will agree with a foreign party to agree in two languages, namely in the Indonesian language and in the language of the foreign party itself, thus there will be no problems regarding the obligation to use the Indonesian language in the agreement. that will be done. 


\section{References}

[1] Lukman Santoso Az. 2012. hukum perjanjian kontrak - cet. 1 - . Yogyakarta : cakrawala

[2] P.N.H.simanjuntak. 2018. Hukum Perdata Indonesia. Jakarta: penada media group.

[3] https://hukamnas.com/asas-hukum-perdata , diunduh pada tanggal 01 November 2019

[4] I ketut oka setiawan. 2018. Hukum Perikatan. Jakarta: sinar grafika.

[5] Subekti. 2019. hukum perjanjian - Cet.19 -. Jakarta: intermasa.

[6] Salim HS.2018. Hukum Kontrak Teori dan Teknik Penyusunan kontrak. Jakarta: sinar grafika.

[7] Agus Yudha Hernoko. 2010. Hukum Perjanjian Asas Proposionalitas Dalam Kontrak Komersial. Jakarta: Kharisma Putra Utama.

[8] Munir Fuady. 2002. Pengatar Hukum Bisnis. Bandung: PT. Citra Aditya Bakti.

[9] Subekti. 2005. Pokok-Pokok Hukum Perdata,Cet. ke-XXXIII. Jakarta: PT.Intermasa.

[10] http://alyaza26.blogspot.com/2011/03/teori-teori-tentang-hukum-kontrak, diunduh pada tanggal 02 November 2019

[11] C.S.T Kansil. 1989. Pengantar Ilmu Hukum dan Tata Hukum Indonesia. Jakarta : Balai pustaka.

[12] Mariam Darus Badrulzaman, dkk. 2001 Kompilasi Hukum Perikatan. Bandung : PT.Citra Adytia Bakti.

[13] Riduan Syahrani. 2000. Seluk Beluk dan Azas-azas Hukum Perdata. Bandung: Alumni Bandung.

[14] Ridwan Khairandy. 2003. Itikad Baik Dalam Kebebasan Berkontrak. Jakarta: Program Pascasarjana Fakultas Hukum Universitas Indonesia.

[15] Suharnoko. 2004. Hukum Perjanjian Teori dan Analisa Kasus. Jakarta: Prenada Media.

[16] Munir fuady, 2001, HUKUM KONTRAK: dari sudut pandang hukum bisnis , Bandung: Citra Aditya Bakti.

[20] Ahmadi Miru, 2011, Hukum Kontrak \& Perancangan Kontrak, Edisi ke-1, Cet. 4, Jakarta: Raja Grafindo Persada.

[23] Sri Soedewi Masjchon, 1980, Hukum Jaminan di Indonesia Pokok-Pokok Hukum Jaminan dan Jaminan Perorangan, Yogyakarta: Liberty.

[24] C.S.T. Kansil. 1983. Pengantar Hukum Dan Tata Hukum Indonesia. Jakarta: Balai Pustaka Jakarta.

[25] A. Qirom Syamsudin Meliala, 2004, Pokok-pokok Hukum Perjanjian Beserta Perkembangannya, Yogyakarta: Liberty.

[26] Munir fuady, 2013, Teori - Teori Besar (Grand Theory) Dalam Hukum, Jakarta: kencana.

[27] Muhammad Syarifuddin, 2012, Hukum Perjanjian, Memahami Perjanjian dalam Perspektif Filsafat,Teori, Dogmatik, dan Praktik Hukum, Bandung: Mandar Maju.

[28] Johannes Ibrahim Kosasih, 2019, kausa yang halal dan kedudukan bahasa Indonesia dalam hukum perjanjian, Sinar Grafika, Jakarta.

[29] Kitab Undang - Undang Hukum Perdata

[30] Kitab Undang - Undang Hukum Pidana

[31] Undang-Undang Nomor 51 Tahun 2009 tentang Perubahan Kedua atas Undang-Undang Nomor 5 tahun 1986 tentang Peradilan Tata Usaha Negara

[32] Undang - Undang No. 24 Tahun 2009 mengenai bendera, bahasa dan lambang negara serta lagu kebangsaan.

[33] https://www.hukumonline.com/klinik/detail/ulasan/lt514689463d4b2/perbedaan-antara-perjanjiandengan-mou/, diunduh pada tanggal 25 desember 2020

[34] Putusan pengadilan Negeri Jakarta Barat putusan Nomor 451/Pdt.G/2012/PN.Jkt.Bar 